\title{
Acidosis Frequency in Children of Pediatric Acute Diarrhea
}

\section{Muhammad Zain Ul Abadin, ${ }^{1}$ Arif Zaheer, ${ }^{2}$ Shahla Tariq, ${ }^{3}$ Muhammad Ans, ${ }^{4}$ Kashif Mehmood, ${ }^{5}$ Moazzam Farooq ${ }^{6}$}

\begin{abstract}
Objectives: To Found out the frequency of aidosis in patients of paediatric accute diarrhea.

Methods: Two hundred and eighty children fulfilling the inclusion/exclusion criteria admitted in Department of Paediatrics, Services Hospital, Lahore was taken. Informed consent of the parents of children was obtained to include their data in the study. Every children with acute diarrhea was followed through 1-2cc arterial sample sent to the hospital laboratory of the hospital.

Results: out of the total 280 patients, $83(29.5 \%)$ had acid base abnormality and $197(70.5 \%)$ had normal acid base imbalance. Out of $83(29.5 \%)$ patients who had acid base abnormality $50(17.5 \%)$ males and $22(8 \%)$ females had acidosis while only $8(3 \%)$ males and 3(1\%) females had alkalosis.

Conclusion: Acidosis is the most common abnormalities. Its incidence increase with increase in duration of diarrhea.

Key Words: Acidosis, paediatric acute diarrhea

How to Cite: Zain-ul-Abadin M, Zaheer A, Tariq S, Ans M, Mehmood K, Farooq M. Acidosis Frequency in Children of Pediatric Acute Diarrhea. Esculapio. 2020;16(04):14-17.
\end{abstract}

DOI: https://doi.org/10.51273/esc20.251643

\section{Introduction}

I n developing countries, Diarrhea still plays key role in both morbidity and death among under-5 children and accounts for $9 \%$ of 5.9 million global under-5 deaths. ${ }^{1}$ Children with diarrhea often present with respiratory difficulties with or without dehydration, and this is mainly due to the presence of metabolic acidosis ${ }^{2}$ resulting mainly from a loss of bicarbonate in feces. ${ }^{3}$ Dehydration is the most frequent and dangerous complication and is the main reason for metabolic acidosis in such children. ${ }^{4}$

The gastrointestinal tract (GIT) helps to regulate

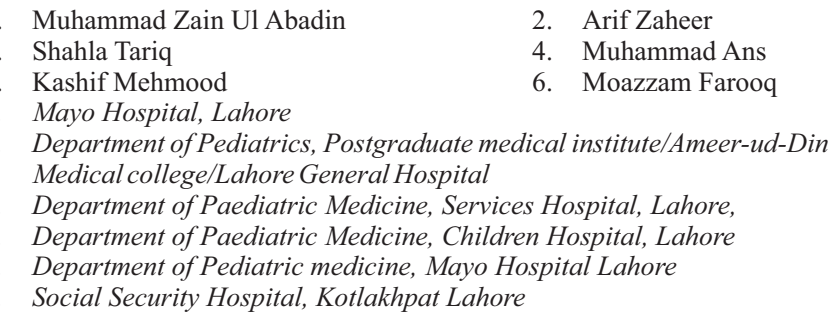

Dr. Muhammad Zain Ul Abadin, Department of Pediatrics, Postgraduate Medical Institute/Ameer-ud-Din Medical College/Lahore General Hospital

Submission Date:

1st Revision Date:

Acceptance Date:
09-09-2020

$02-12-2020$

$14-12-2020$ acid-base homeostasis. Large amounts of $\mathrm{H}+$ and $\mathrm{HCO}_{3}$ cross the specialized epithelia of the various components of the gut every day, but under normal conditions, only a small amount of alkali (approximately 30 to $40 \mathrm{mmol}$ ) is lost in the stool. ${ }^{5}$ The small amount of alkali lost as a byproduct of these transport events is easily regenerated by renal net acid excretion, which is regulated by the kidney to maintain body alkali stores. Disruption of normal gut function, however, uncovers its power to overwhelm acid-base homeostasis. Acid-base disorders can vary from severe acidosis to severe alkalosis, depending on the site along the gastrointestinal tract affected and the nature of the losses that ensue. ${ }^{6}$ These disruptions in acid base equilibrium are associated with disorders of either potassium imbalance or sodium imbalance. ${ }^{7}$

The type of diarrhea depends on which part of the GIT has been targeted and the causative agent. ${ }^{8}$ Commonly observed acid base disturbances in diarrhea are hyperchloremic metabolic acidosis and metabolic alkalosis occurs in very few types. ${ }^{9}$ In secretory diarrhea, like caused by Vibrio Cholera, there is hyperchloremic metabolic acidosis. Lactic acidosis may supervene as a result of tissue hypoperfusion. ${ }^{10}$ In 
inflammatory diarrhea, there is no acid base disturbance initially as kidney is compensating for the loss, however, in severe cases, volume depletion and hyperchloremic metabolic acidosis may occur. In case of autoimmune diarrhea, incidence of metabolic alkalosis is more. ${ }^{11}$ A study was conducted in Bangladesh reported higher incidence of morbidity and mortality in children who developed metabolic acidosis and suggested that early recognition of features of acidosis may help clinicians to have prompt management that may further help reduce mortality in such children. ${ }^{12}$ As it is a common cause of morbidity and mortality in Pakistan, and limited literature is available in reference to acid base imbalance and there is no research done on this important issue in my center. Young children die of this simple problem, so my rationale is to highlight the major cause which lead to death from this simple problem.

\section{Methods}

It was a cross sectional study which includes 280 cases. Sampling was done by Non probability consecutive sampling technique. Our inclusion criteria was children between 3 months to 5 years of age and children with acute diarrhea (Passage of loose or watery stools at least 3 times in 24 hours, for less than 14 days). Children having any chronic GI illness like celiac disease and congenital adrenal hyperplasia and children having other systemic disease like renal (urea $>20 \mathrm{mg} / 1$, creatinine $>1.3 \mathrm{mg} / \mathrm{dl}$ ), gastrointesti- nal and metabolic diseases were excluded from the study because these cases will act as effect modifiers and if included in the study will introduce bias in the result. The collected data was entered and analyzed using SPSS version 16. The frequency and percentage of children with acid base imbalance whether acidosis or alkalosis were noted. Data was stratified for age, acid base imbalance, gender, duration of diarrhea to address the effect of modifiers. Chi-square test was used to compare qualitative data. $p<0.05$ was considered as significant.

\section{Results}

We found out that, out of 280 cases $140(50 \%)$ were in the age range of 3-12 months. When they were divided according to gender, $148(53 \%)$ were male and $132(47 \%)$ were females. When acid base balance was checked. Out of the total 280 patients, $83(29.5 \%)$ had acid base abnormality and 197(70.5\%) had normal acid base balance. Out of 83(29.5\%) patients Table 1: Distribution of Acid Base Imbalance $(n=280)$.

\begin{tabular}{lcccc}
\hline \multicolumn{1}{c}{$\begin{array}{c}\text { Acid Base } \\
\text { Imbalance }\end{array}$} & Male & Female & Total & $\begin{array}{c}\text { p- } \\
\text { value }\end{array}$ \\
\hline $\begin{array}{l}\text { Acidosis } \\
\text { pH }<7.35\end{array}$ & $50(17.5 \%)$ & $22(8 \%)$ & $72(25.5 \%)$ & 0.005 \\
$\begin{array}{l}\text { Alkalosis } \\
\text { pH }>7.45\end{array}$ & $8(3 \%)$ & $3(1 \%)$ & $11(4 \%)$ & 0.001 \\
$\begin{array}{l}\text { Normal } \\
\text { pH 7.35-7.45 }\end{array}$ & $109(39 \%)$ & $88(31.5 \%)$ & $197(70.5 \%)$ & 0.054 \\
\hline
\end{tabular}

who had acid base abnormality, 50(17.5\%) males and $22(8 \%)$ females had acidosis while only $8(3 \%)$ males

Table 2: Stratification of Acid Base Imbalance with Regard to Age Range, Number of Diarrheal Episodes and Severity of Dehydration $(n=280)$.

\begin{tabular}{|c|c|c|c|c|}
\hline \multirow{2}{*}{$\begin{array}{l}\text { Stratification of frequency acid base imbalance } \\
\text { with regard to age range }\end{array}$} & \multicolumn{3}{|c|}{ Age Range } & \multirow{2}{*}{ p-value } \\
\hline & $\begin{array}{c}3 \text { - } 12 \text { months } \\
(n=140)\end{array}$ & $\begin{array}{c}13-24 \text { months } \\
(n=81)\end{array}$ & $\begin{array}{l}25 \text { months - } 5 \text { years } \\
(n=59)\end{array}$ & \\
\hline Acidosis & $51(36.4 \%)$ & $20(31 \%)$ & $6(10 \%)$ & 0.025 \\
\hline Alkalosis & $6(4.5 \%)$ & $2(4.6 \%)$ & $0(0 \%)$ & 0.300 \\
\hline Normal & $90(64.2 \%)$ & $62(69 \%)$ & $53(90 \%)$ & 0.001 \\
\hline \multirow{2}{*}{$\begin{array}{l}\text { Stratification of frequency acid base imbalance } \\
\text { with regard to number of episodes }\end{array}$} & \multicolumn{4}{|c|}{ Number of episodes } \\
\hline & $\begin{array}{c}1-3 \\
(n=146)\end{array}$ & $\begin{array}{c}4-5 \\
(n=78)\end{array}$ & - & \\
\hline Acidosis $<7.35$ & $21(25.5 \%)$ & $26(28 \%)$ & $25(38 \%)$ & 0.001 \\
\hline Alkalosis $>7.45$ & $4(4 \%)$ & $2(2 \%)$ & $5(7.6 \%)$ & 0.025 \\
\hline Normal 7.35-7.45 & $57(70 \%)$ & $65(70 \%)$ & $25(38 \%)$ & 0.005 \\
\hline \multirow{2}{*}{$\begin{array}{l}\text { Stratification of frequency acid base imbalance } \\
\text { with regard to severity of dehydration }\end{array}$} & \multicolumn{3}{|c|}{ Severity of Dehydration } & \\
\hline & No dehydration & No dehydration & No dehydration & \\
\hline Acidosis $<7.35$ & $11(20 \%)$ & $30(18.3 \%)$ & $31(47 \%)$ & 0.001 \\
\hline Alkalosis $>7.45$ & $3(5 \%)$ & $2(1.9 \%)$ & $6(9 \%)$ & 0.025 \\
\hline Normal 7.35- 7.45 & $31(86 \%)$ & $87(73 \%)$ & $26(40 \%)$ & 0.005 \\
\hline
\end{tabular}


and 3(1\%) females had alkalosis as shown in Table-1. Data was than stratified with age, number of diarrhea episodes and severity of dehydration using chi-square test as shown in Table-2.

\section{Discussion}

Acidosis is the most common acid base imbalance in our study population. $25.5 \%$ who presented with diarrhea also had acidosis. In a study conducted by Sharifuzzaaman et al in 2017 in Bangladesh they reported acidosis in $96 \%$ of the children who presented with watery diarrhea. ${ }^{12}$ These results are very higher than ours it may be due the fact that they have included patient only with complain of acute watery diarrhea whereas we included cases of diarrhea with any cause of origin. In a study conducted in Kathmandu, Nepal 94\% children who presented with diarrhea had acidosis whereas only one $6 \%$ had alkalosis. ${ }^{13}$ Similar results have been reported by Habib Ullah. ${ }^{14}$ Narchi reported that there is no significant difference between the serum bicarbonate concentrations in relation to the degree of dehydration in diarrhea patients. ${ }^{15}$ Shah reported that increase incidence of acidosis in diarrhea is due to more loss of bicarbonate from gastrointestinal tract. ${ }^{13}$ When frequency of acidosis is stratified with age range, it is found that acidosis is more frequent in the 3-12 months age group. Similarly, in a study conducted by Eke C Bet al in Nigeria they reported Children less than 12 months of age were three times more likely to have acidosis (odds ratio $=3.098$ ) than those above 12 months. This may be related to the high body surface area in the younger infants, thereby predisposing them to greater loss of fluid and electrolytes. ${ }^{16}$ Acidosis is also more common in the group with diarrhea of more than 6 days (44.4\% in the third group). This is due to the fact that as duration of diarrhea prolongs increase faecal losses of sodium, potassium and bicarbonate leads to more loss which are not being replaced properly due to the improper rehydration methods and lack of awareness about continuation of breastfeeding during diarrhea in Pakistani mothers, according to Bello DA. ${ }^{17}$ This also suggest that early presentation and prompt correction of this derangement may reduce the duration of diarrhea and by extension associated mortality as corroborated by other studies. ${ }^{18,19}$ Acidosis is present in the group with no dehydration The reason is that in these patients, loss of water was replaced by hypotonic solutions but the loss of elec- trolytes were not properly compensated. However, its incidence is much higher in the group with severe dehydration. Loss of more bicarbonate as compare to Hydrogen leads to increase incidence of acidosis in severely dehydrated patients. ${ }^{20}$

\section{Conclusion}

Acidosis is the most common acid base abnormality in children with acute watery diarrhea. Children less than 2 years of age are most affected. Frequency of acidosis increases with an increase in duration of diarrhea and occur more frequently in patients who are severely dehydrated. All children especially less than 2 years of age must be properly dehydrated. ORS should be started immediately and in proper amounts once diarrhea starts.

\section{Conflict of Interest: $\quad$ None}

\section{References}

1. UNICEF. Committing to child survival: a promise renewed. Progress report 2015. http:// www. apromiserenewed.org/wp-content/uploads/ 2015/ 09/ APR 2015_8_Sep_15.pdf. Published September 2015. Accessed October 16, 2017.

2. Saha D, Ronan A, Khan WA, Salam MA. Diagnosis of pneumonia in children with dehydrating diarrhoea. J Health Popul Nutr. 2014; 32:14-18.

3. Chisti MJ, Salam MA, Bardhan PK, et al. Influences of dehydration on clinical features of radiological pneumonia in children attending an urban diarrhoeatreatment centre in Bangladesh. Ann Trop Paediatr. 2010;30:311-316.

4. Okposio MM, Onyiriuka AN, Abhulimhen-Iyoha BI.Point-of-admission serum electrolyte profile of children less than five years old with dehydration due to acute diarrhoea. Trop Med Health. 2015;43:247252.

5. Stumpff F. A look at the smelly side of physiology: transport of short chain fatty acids. Pflügers ArchivEuropean Journal of Physiology. 2018 Apr 1; 470(4): 571-98.

6. Orban JC, Ichai C. Alkalosis: Diagnosis and Treatment. InMetabolic Disorders and Critically Ill Patients 2018 (pp. 195-214). Springer, Cham.

7. Kaptein E, Sreeramoju D, Kaptein J, Kaptein M. A systematic literature search and review of sodium concentrations of body fluids. Clinical nephrology. 2016 Oct 1;86(4):203

8. Berend K, de Vries AP, Gans RO. Physiological approach to assessment of acid-base disturbances. 
New England Journal of Medicine. 2014 Oct 9; 371 (15): 1434-45.

9. Abdallah MS, Warodi FA, Gambo RM. Antibacterial Activity of Leaf Extract (Cassia Mimosoides Linn) on some Bacterial isolates from diarrhoeal samples of infant. Imperial Journal of Interdisciplinary Research. 2017;3(1).

10. Reddi AS. Acid-Base Disorders in Gastrointestinal Diseases. In Acid-Base Disorders 2020 (pp. 157170). Springer, Cham.

11. Steffer KJ, Santa Ana CA, Cole JA, Fordtran JS. The practicalvalue of comprehensive stool analysis in detecting the cause ofidiopathic chronic diarrhea. Gastroenterol. Clin. North Am. 2012; 41:539-60.

12. Sharifuzzaman, Sarmin M, Ahmed T, Alam T, Islam $\mathrm{SB}$, Islam MM, Chisti MJ. Determinants and outcome of metabolic acidosis in diarrheal children under 5 years of age in an urban critical care ward in Bangladesh. Global Pediatric Health. 2017 Nov 3;4: $2333794 X 17740223$.

13. Shah GS, Das BK. Acid base and electrolyte disturbances in diarrhea. Kathmundu Univ Med J 2007; 5: 60-2.

14. Habibullah B, Sanaullah, Muhammad R. Serum Electrolyte Disturbances in Acute Diarrhoea among Children Less Than 5 Years of Age. P J M H S 2016; 10: 1231-3.

15. Narchi H. Serum bicarbonate and dehydration severity in gastroenteritis. Arch Dis Child 1998; 78: 7071.
16. Eke CB, Ndu IK, Edelu BO, Uleanya ND, Ekwochi U, Chinawa JM, Nwokoye IC, Ikefuna AN. Clinical profile and electrolyte abnormalities in hospitalized under-five children with acute gastroenteritis in a tertiary health facility. Nigerian Journal of Medicine. 2020 1;29(2):295.

17. Bello DA, Afolaranmi TO, Hassan ZI, Ogbonna FC, Inedu PG, Ejiga C, Chirdan OO. Knowledge and use of oral rehydration solution in the home management of diarrhea among mothers of under-fives in Jos, Plateau State. 2017

18. Al-Abbas AK. Etiology of bacterial diarrhea in children under five years in Kerbala Province, Iraq. Iraqi Journal of Public Health. 2018 May 4;2(1):2-6.

19. Shahrin L, Chisti MJ, Huq S, Nishath T, Christy MD, Hannan A, et al. Clinical manifestations of hyponatraemia and hypernatraemia in under-five diarrhoeal children in a diarrhoeal hospital. J Trop Pediatr 2016; 62:206-12.

20. Ahmad TM, Mehmood A, Malik TM, Aamir M. Pattern of acid base abnormalities in critically ill patients. Pakistan Armed Forces Medical Journal. 2015 Feb 28;65(1):99-104.

\section{Author's Contribution}

AZM: Sampling, introduction \& results

ZA: Critical review \& hypothesis development

TS: Sampling \& discussion

AM: Sampling \& introduction

MK: Sampling \& results

FM: Sampling \& statistical analysis 